\title{
The government and urban structure unsustainability in Iran
}

\author{
A. A. Pilehvar ${ }^{1}$ \& N. Kamali ${ }^{2}$ \\ ${ }^{I}$ Department of City Planning, Bojnourd University, Iran \\ ${ }^{2}$ Education North Khorasan Organization, Iran
}

\begin{abstract}
The government in Iran, in the recent century, has played a crucial role in structural changes, particularly in cities. These changes have been made due to political division, land reforms, economical investment and performing urban development schemes in various geographical regions. After the Mashroota Revolution in 1907 and petroleum discovery in Iran, the government's political decisions and oil-centred economical development led to a change in national economy from dependency on agricultural and livestock production to oil incomes. The research results indicate that before the Islamic Revolution in 1979, the government had created functional and structural changes in the urban network and hierarchy with a capitalistic and modernistic approach and the instrumental use of oil. The changes resulted in such outcomes as racial variation, rural to urban migration, urban-regional inequality, the increasing growth and development of cities and in general urban structure sustainability. Following the Islamic Republic of Iran, the government's political decisions with an Islamic-sociological approach and socio-economical programming have influenced urban growth and development sustainability and have brought about challenges such as the reduction in urban economical efficiency, decline in urban environment quality, life quality diminution, housing crisis, etc. This paper seeks to study critically, analytically and using documental studies the contribution the government and its political decisions had in the urban structural changes in Iran in the recent century. Moreover, using documental data, the authors have presented statistical tables and diagrams, the levels of analysis and socio-economical and political structure in general and the urban structure sustainability of Iran in particular.
\end{abstract}

Keywords: government, economical-social development, oil incomes, urban structure, unsustainably, Iran. 


\section{Introduction}

The government in Iran, as the most significant political factor and social economical planner, has hithermost influence on the structural changes, particularly in cities. After the Mashroota Revolution in Iran in 1907 came urban development, in which the government was considered as a new element in the transformation and change of the structure and function of cities along with old elements such as bazaars, etc. Relying on oil income, the new element with the establishment of the official system entered the domain of urban economy and development [1]. Therefore, the national economy, on the one hand, transformed from dependency on oversupply of livestock and agricultural productions to oil income and, on the other hand, the appearance of petroleum as new goods in the global market in the early 2000 s was considered a valuable instrument so that the government could develop the future and establish industrial and company towns with structural and urban renewal. Thus, the government, relying on the oil income, has maintained a crucial role in the structural changes and urban organic development of Iran. Thanks to modernism, industrialism, inciting people towards urbanization and urbanism, investment in cities and designing and accomplishing urban development programs, structural-functional changes have been created in the urban network and urban hierarchy of Iran. The result of such an approach has been the deep social-economical gap, extensive rural to urban migrations, unreality of urban growth and development, excessive expansion of cities and internal sustainability in the urban structure. Moreover, political decisions of the government (the government's political decisions) on reinforcing the position of the cities has resulted in ignorance from suburb (villages) and caused urban-regional instability. Furthermore, political decisions of the government and decentralization, after the 1979 revolution, have affected the urban structural instability and have brought about challenges and problems, such as the reduction of urban economical productivity, decrease of urban environment quality, decrease in life quality and public benefit diminution [2]. This article analyses the role of the government's political decisions on the urban structural changes and with a critical approach and using documental data has studied the government's decentralization and outcomes of oil income on the urban growth and development and urban system and structure changes during the recent century.

\section{Research plan}

The changes in Iran in the recent century indicate performing social-economical and cultural development plans and a modernistic approach that has accelerated urbanism urbanization and has turned minor towns in to large ones and large towns into metropolises. Moreover, acceleration in the anatomical growth of the cities has led to structural problems in the lack of services, increase in social problems, magnetization, the division of anatomy of between north and south, etc. The rapid growth and development of Iran's cities influenced by oil-oriented economical development and the approach to industrial modernism in the urban 
system and urban network has appeared. Also the government's political approach in directing marking cities and performing structural programs has led to regional-urban inequality and change in the urban hierarchical system. This trend shows a level of national development inequality with structural changes in cities accompanied with the economical (urban poverty, increase in the rate of unemployment), social (magnetization, racial gap) challenges (reduction of life quality) and environmental threats.

\section{Research questions}

The description of urban challenges and problems in the most recent years suggests that the government has had an effective role in directing and developing cities, and, in addition, that its political decisions administrating social-economical development programs that increase the rate of urbanization, the number of cities and metropolises, changes in the urban network and system, etc, indicate the role of the government in dependency on the oil income and mono product economy. Thus, the question is, first how can the government play its powerful part in the urban development process of Iran compared with traditional elements such as market, etc. Secondly, how does the structural concentration of the government because of oil income influence urban inequality and instability.

\section{Research hypotheses}

As for the mono product economy of Iran and 70\% dependency of national economy on oil and oiled income, urban growth and development has been influenced by political decisions and the oil economy, which put forward the following hypotheses: 1 . the effect of oil incomes in political decisions of the government for urban structural changes, particularly metropolises, has been negative; 2 . the political approach towards administrator urban development has had a positive role in the urban structural inequality.

\section{Literature and theoretical basis}

\subsection{The government and political management}

Political science theorists, with regard to the position and role of the government in local growth and development, emphasize the active presence of the government in social-economical life domains and find that it is difficult to have progress without the government undertaking [3]. At present, the government, having tendencies and constitutions, plays an essential role in the civilization and social correlation. To put it another way, the government reinforces the ruling [4]. With this approach, the government plays a special part in the economical (formational growth and development), social (reduction of inequality and racial gap, national correlation), cultural (maintaining values and promoting cultural foundation of the country), political (stability and existence of the country) and 
environmental (decreasing pollutants, maintaining balance in the environment...) dimensions. If the position and authority of the government were sustainable, it would lead to a proper government that will result in the structural-functional changes process. Figure 1 shows the relationship between the positive role of the government and urban structural stability. In this figure, the effect of the government's political decisions on the stability of urban growth and development (providing opulence) is well expressed.

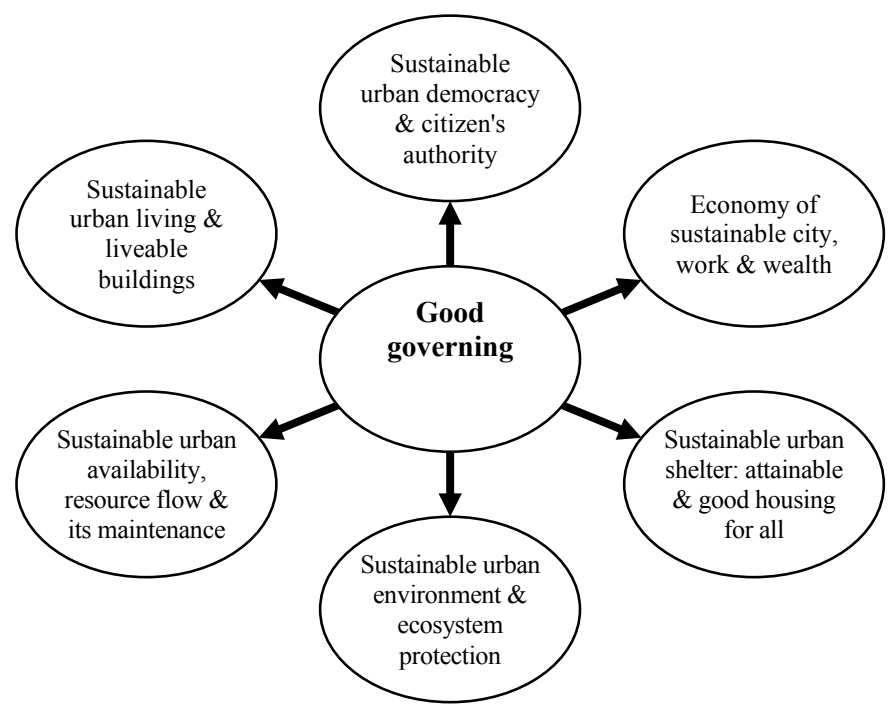

Figure 1: Relationship between the positive role of the government and urban structural stability.

\subsection{Functional-structural theory of government in the urban system of Iran}

The government in Iran formalizes the specific path that the law has designated and fulfils the determined programs on the basis of Islamic thoughts and ideology according to social justice and the reduction of inequality at national, regional and local levels. Obviously, realization of these programs by the government has produced structures, the majority of which have been crystallized as an urban system and managing the government, which is originated from people, and the nation has an outstanding effect on the appearance of urban system structures. For instance, centralization in Tehran or establishing regional development poles as 5-7 year development programs before the 1979 revolution has affected the appearance of five metropolises in Iran and severe marginalization problems and immethodical rural-urban migrations have emerged. In addition, after the 1979 revolution, by sculpturing the urban system of Iran, the government has presented socially-economically and culturally various patterns that it has used to organize the environment as bipolar and multi polar and this has led to economical-social functions and a 
system with different features and has showed the role of the government in organizing urban space and its structural changes [5].

\section{Paradigm urban planning}

Urban planning theories in the early 20th century show the relationship between organist and function as a list theory in urbanization during the modernism period (Athena charter, 1933) [6]. The result of this process was the appearance of a comprehensive planning pattern (preparing detailed and comprehensive urban plans) in urbanization and urban planning with a positivist and individualist approach, which continued until the 1960s. From the second half of the 20th century, modernism was challenged for a few decades and post-modernism was the prevailing thought. In the beginning of 21 st century, along with the globalization process, the human community entered into a new era called the communication era and the network society [7]. Thus, post-modernism and modernism raised new theoretical concepts and bases in urban planning and urbanization, which include strategic planning in 1960, incremental planning, advocacy planning, equity planning in 1965, democratic planning in 1985 in Britain and the United States, systemic planning in 1965-8, process planning in 1973 and collaborative planning in 1990 [8]. In the recent decades, urban and regional planning theories have undergone fundamental changes, each of which have played an important part in a specific time zone and are raised as comprehensive or rational planning paradigms, a systemic planning paradigm and a strategic planning paradigm. To explain the formation process, intellectual foundations and the purposes and patterns of urban development plans in 20th century, table 1 is presented.

Table 1: $\quad$ The changes of urban planning in the 20th century.

\begin{tabular}{|c|c|c|c|c|}
\hline Paradigms & Influence & $\begin{array}{l}\text { Intellectual and } \\
\text { social basis }\end{array}$ & Major goals & $\begin{array}{c}\text { Paradigm of } \\
\text { development plans }\end{array}$ \\
\hline $\begin{array}{l}\text { Comprehensive } \\
\text { planning }\end{array}$ & $1920-1960$ & $\begin{array}{c}\text {-Rationalism \& } \\
\text { position } \\
\text {-Centralized } \\
\text { government } \\
\text { management }\end{array}$ & $\begin{array}{c}\text {-Economical } \\
\text { major } \\
\text { development } \\
\text {-Physical } \\
\text { organization }\end{array}$ & $\begin{array}{c}\text {-National, } \\
\text { regional \& local } \\
\text { plans } \\
\text { Comprehensive } \\
\text { \& detailed plans }\end{array}$ \\
\hline $\begin{array}{l}\text { Systemic } \\
\text { planning }\end{array}$ & $1960-1680$ & $\begin{array}{l}\text {-Systemic view } \\
\text { towards world } \\
\text {-Scientific } \\
\text { management of } \\
\text { systems } \\
\end{array}$ & $\begin{array}{c}\text {-Improving } \\
\text { social-economical } \\
\text {-Supervision \& } \\
\text { direction of city }\end{array}$ & $\begin{array}{c}\text {-Urban system } \\
\text { modelling } \\
\text {-Long-term plans } \\
\text {-Local-Structural } \\
\text { plans } \\
\end{array}$ \\
\hline $\begin{array}{l}\text { Strategic } \\
\text { planning }\end{array}$ & $1980-2000$ & $\begin{array}{c}\text {-Strategic view \& } \\
\text { decision making } \\
\text {-Democracy \& } \\
\text { collective } \\
\text { thinking } \\
\text {-Native \& local } \\
\text { values } \\
\text { guardianship }\end{array}$ & $\begin{array}{c}\text {-Providing } \\
\text { sustainable } \\
\text { development } \\
\text {-Spread of social } \\
\text { justice } \\
\text {-Reinforcing } \\
\text { collective } \\
\text { collaboration }\end{array}$ & $\begin{array}{l}\text {-Hierarchy of } \\
\text { plans } \\
\text {-Types of local } \\
\& \text { short-term } \\
\text { plans } \\
\text {-Urban design } \\
\text { project }\end{array}$ \\
\hline
\end{tabular}




\section{Iran's approach towards urban planning}

Modernity in Iran was developed by politicians, not experts, and mimicry of the west in national growth and development led to a crisis rather than development. From another angle, as it was government-oriented, political and imitative, the approaches towards planning for local and national-regional development have been unsuccessful [9]. In Iran and most developing countries, however, executive pre-conditions and infra structures for strategic planning have not been provided and the government does its best to establish substructures, remove structural obstacles and provide primary services for city growth and development, through compatibility and equality improvement and correcting methods are preferable in the structural changes of urban development. Hence, the current urban planning process in Iran, with its traditional methods, has produced the following challenges and obstacles in the urban structure sustainability.

\subsection{Weakness in social-economical substructures}

During the second half of the recent century, the entire political-economical, social and cultural structures of Iran influenced a set of intrinsic and extrinsic factors that were subject to rapid changes. Vast transformation in the whole population structure of the country, along with vast social and spatial movement, is observed in Iran. This process has envisaged future planning, development and challenges, including the rapid growth and migration of the population, lack of land and housing. It has been expensive and has led to magnetization growth, environment pollution and welfare and service needs for which there is not enough substructure and facilities to qualify as habitual space and sustainable conditions [10].

\subsection{Inconsistency in planning system and development management}

During the past 60 years, a series of laws and regulations pertaining to urban development and cultivation in Iran have been established that have influenced the urbanization changes and urban management. These include municipality laws (1955), establishment of the housing department (1964), the urban land law (1988), land monitoring (1993), etc, all of which are owned by different institutes and organizations and are only partially executed and there is not the required consistency.

\subsection{Legal possession issues and land usage}

One of the fundamental weaknesses of the detailed and comprehensive urban plans that are currently executed in Iran is the deficiency or inadequacy of laws related to owners' equity and supervision of urban lands. Urban development plans in Iran are based on a comprehensive planning system in which attention is paid to programs of land usage, a land usage map, usage per capita tables and regionalization principles, whereas social, economical, environmental and legal 
aspects and good use of urban lands for the public interest and the supervision of the economy of land building should be taken into serious consideration.

\subsection{Weakness of urban management foundations and local planning}

One of the most important principles in strategic planning is to have authority to plan locally and to pay attention to the local needs and values. Thus, lack of enough experience and centralized governmental management have played an important part in planning execution weakness and urban management. The first law for municipality establishments and city associations was approved in 1907 [11]. The execution of the municipality law was in 1955 and that of the Islamic council was in 2000 .

\subsection{Reduction of public collaboration in urban development and cultivation}

In the current urban structure process, the role of the private sector and its collaboration conditions in the urban development and cultivation plans have not been defined specifically. Also, professional associations, such as architects and the councillor engineer society, do not undertake any effective role in decision making, administration, recurrence or supervision. Public associations and nongovernmental organizations pass their embryonic periods and do not have an active role in urban development or the cultivation process. Instead, the government has had an active role in the urban development and cultivation of Iran [12].

\section{The effect of oil incomes on urban structure (1920-1979)}

After the 1921 coup, the new Pahlavi national modern government in the Persian Gulf region considered the cities to be an indication of new era, along with the improvement and industrialization period. The first incentive to industrialization was during the 1920s, during which movement of the forces led to the appearance of the primate city of Tehran. For the first time in this process and in the urbanization history of Iran, oil incomes have played a part in the physical growth and development and urban spatial metamorphism with an extrinsic approach. Building streets as an indication of modernism, imitating humans' urbanization, was performed along with the first law for developing passages and streets in 1933 [13]. The Pahlavi government, with a combined approach to the socialism-capitalism system, attempted to transform Iran's society and subordinated the manufacturing system by performing land reforms in 1962, creating a montage industry in 1967 and attending to global work distribution and subsequently drove Iran's community towards a consumption and service society. On the other hand, the city lowered its dependency on the villages and investment and goods flow in the city flourished, along with business, and cities changed into a stock of wealth and capital and a place for rural migration. This was the beginning of the dependency of the cities on the government and the oil economy in Iran. Urban land was profitable and goods determining the growth of 


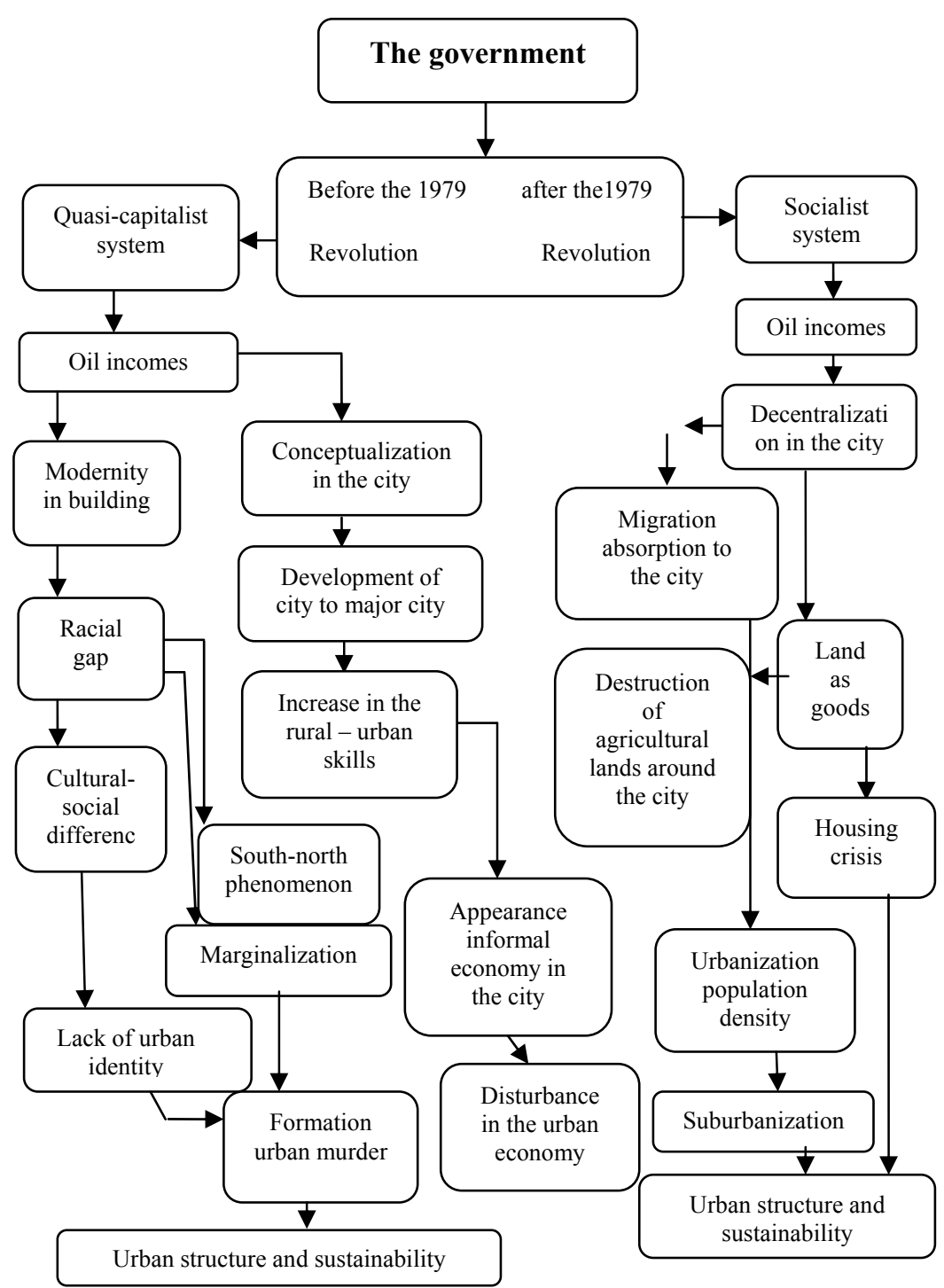

Figure 2: The government and the urban structure unsustainably in Iran before and after 1979 .

the cities and the establishment of industrial centres around them. In particular, metropolises influenced the centralization and urban-rural migration. For the first time, in the third development program of 1962-66, the government paid attention to the urban comprehensive plans based on rational and comprehensive planning and took urbanization as a specific issue into consideration. The establishment of a housing and development department in 1964 was a reaction to the problematic cities in Iran. A city that was born after the formation of the 
consumer society is based on manufactured organization and the government, relying on the oil economy, tried to organize the urban space and form an urban network in Iran. Iran's oil income was multiplied in 1973 and the extensive budget of the government clearly influenced the quick growth of industry, work power, land and building. This process has led to urbanization around big cities and the destruction of agricultural lands around them, the creation of new industrial cities, such as labours, rural-urban migration absorption and in general urban economy disturbances and changes in the structure of cities. This continued until the Islamic revolution of Iran in 1979. The results of the government's tendency towards urban growth and development are presented in figure 2. This figure shows the relationship between a socialist (after the1979 revolution) and quasi capitalist (before the 1979 revolution) government and the effects of this approach on urbanization issues and the urban structure of Iran in the recent decades.

\section{Urban development from the 1979 revolution to 2009}

Societies that have a flourishing Islamic culture and civilization have created the most populous and prosperous urban centres in the new era. Facing modern institutions, they have undergone tremendous transformation, particularly in the cities [14]. One of these transformations is the rapid population growth in urban centres in the world of Islam. For instance, the population of Tehran, as the capital of Iran, increased from 500000 people in the mid $1930 \mathrm{~s}$ to in excess of 8.5 million people in 2009, a 17 times increase [15]. The approach and concentration of the activities in big cities and metropolises on the one hand, and urban population growth and motivating urbanism and urbanization, on the other hand, has led to extreme structural transformation in recent decades. Population growth percent suggests that fundamental changes have appeared in the social and urban structure of Iran. A formal census shows that the population growth rate was 2.7 in the 1970 s and 3.9 in the 1980 s. This rate has affected the annual urbanization growth and the rate of 4.9 in the 1970 s has reached to 5.38 in the 1980s. According to the data gained from Iran's census centre, the urbanization rate increased in the $1970 \mathrm{~s}$, having risen from $47 \%$ in the $1970 \mathrm{~s}$ to $54.3 \%$ in the 1980s. The urban population growth process, annual growth rate and urbanization percent continued have continued to increase in the last 10 years and the urbanization rate in 2006 had risen to $68.3 \%$. Table 2 provides formal data related to urban and population changes in Iran. In this table, the rate of urbanization growth, annual growth percent and urbanization shows that there have been some fundamental changes in the life patterns of people, from living in villages to urbanization after the 1980s.

According to table 2, social changes in particular show that the life pattern in Iran has changed from realization to urbanization and stresses the importance of the city and urban development issue. Urban population growth and physical and skeletal development of the cities into surrounding lands has led to an increase in the demand for housing and urban land and thus a housing crisis. In the 1990s, to 
Table 2: Urbanization growth rate, annual growth percent, and urbanization in Iran.

\begin{tabular}{|c|c|c|c|c|c|c|}
\hline Year & Population & $\begin{array}{l}\text { Annually } \\
\text { growth }\end{array}$ & $\begin{array}{c}\text { Urban } \\
\text { population }\end{array}$ & $\begin{array}{c}\text { Urbanization } \\
\text { Annually } \\
\text { growth }\end{array}$ & $\begin{array}{c}\text { Urbanization } \\
\text { percent }\end{array}$ & $\begin{array}{l}\text { No. of } \\
\text { city }\end{array}$ \\
\hline 1956 & 18955000 & 1 & 5954000 & - & 31.4 & 199 \\
\hline 1966 & 25789000 & 3 & 9794000 & 5.1 & 38 & 271 \\
\hline 1976 & 33709000 & 2.7 & 15855000 & 4.9 & 47 & 373 \\
\hline 1986 & 49445000 & 3.9 & 26845000 & 5.3 & 54.3 & 498 \\
\hline 1996 & 60055000 & 2.9 & 36800000 & 4.6 & 61.3 & 612 \\
\hline 2006 & 70495782 & 1.6 & 48245075 & 6.1 & 68.3 & 1015 \\
\hline
\end{tabular}

Source: Iran's census centre, public census of people and housing, 1956-2006, whole country.

decentralize metropolises and campaign against suburbanization phenomena, housing expensiveness, abnormal growth and development of the cities, urban environment unsustainably, etc, the government sought to plan new peripheral cities. Rural to urban migration and urban to urban migration have reached $21.7 \%$ and $64.6 \%$, respectively [16]. As a result of urban growth and development and the prosperity of servitude-industrial activities, disturbances in the urban network have been revealed along with weaknesses in the structural-strategic planning and industrial pattern performance, which threaten the urban environment, informal urban inhabitants and led to a housing crisis. Structural changes and urban issues have an economical background, so that oil incomes, along with the rural population migration to urban areas, has reinforced the focus on urbanization and exposed the sustainability of development to environmental and inappropriate social-economical challenges.

\section{Answer to the hypothesis}

The oil price increase in 1973 influenced the qualitative and quantitative development of the cities and has had a tremendous effect on the structure of the cities' special position (role) in the national economy and change in the structure of cities. Population growth and the increase in the number of cities and metropolises changed the urban system and network of Iran profoundly. Rural to urban life pattern changes caused the urbanization rate to reach $68.3 \%$ in 2006 . Centralized governmental management, performing up-to-down development strategies in national and regional-local development programs and a lack of active social collaboration in the urban function and structure show the government's clear role in urban development management in Iran. Traditional methods, structural weakness, legal and development management, local planning and the reliance on oil income for structural changes in the urban system and network have led to inequality in the urban-regional network, informal inhabitants, an urban land and housing crisis, environmental issues in cities, etc., all of which result from the political approach of the government in directing and planning schemes and urban development. 


\section{Conclusions}

In the second half of the 20th century, Iran's economy has been faced with political, social and economical shocks and has experienced an oil-centred economy due to the severe dependency on oil incomes. Moreover, social-economical development programs have played a significant role in the national, regional and local (urban) issues and challenges. Therefore, cities in Iran influenced by economics, social growth and development and population dimensions in the flow of modernist changes developed spatially into surrounding lands and this has led to the emergence of large and small cities. On the other hand, policy making in urban development management presents a method of imposing order for systematic and programmable growth and development. At present, one of the fundamental problems in the management system is planning urban development where the common and standard ways and principles do not correspond to the principles of sustainable development and values about citizenship rights and social justice .etc, since the existing planning and management system is inherently based on the legislation and authority of the central government and is unable to respond to local native needs [17]. To exert changes, review the current management system and perform urban development plans, structural-strategic planning patterns should be sought with gradual reforms in different legal, official, technical and administrative domains. so, it is suggested that structural weakness should be removed from urban planning and the urban development process in Iran and it is necessary to provide the programs and schemes with a strategic approach to meet the interests of social categories and an Iranian-Islamic effective example for urban planning is presented.

\section{References}

[1] Aliakbari, Esmaeel and Faraji Daralikhani Mohammad., Official-Political Cities and Urban unsustainably, A case Study of Sarayele Town, Geography and Regional Development Magazine, Number 6, Spring and Summer, p. 161. 2006

[2] Nazarian, Asghar., Metropolitan Region and Its Spatial manifestation, A case Study on Tehran, Geographical Quarterly of territory, 2nd year, Number 77. 2005.

[3] Allmendinger , P. H, and Mark Tawdry ,Jones Planning Futures ,New Directions for Planning Theory, Rutledge, London and New York. 2002.

[4] Shojaee Zand, Alireza. Religious Authority of the Government, Political Power of Religion, Tebyan Publications. 1997.

[5] Azimi, Naser, Urbanization exploration and Median of Urban System, Nashre Nika Publications. 2004.

[6] Ziari, Keramatolla. New Urban Planning, Samt Publications, PP 14-15. 2005. 
[7] Castles, Manuel. Information Age, Economy, Society and Culture (Appearance of Network Community), Translated by Ahad Aligholian and Afshin Khakbaz, vol 1, Nashre no Publications, P. 48. 2002.

[8] Pirzade, Revision of Urban Development Management System in Iran Based on a Strategic Approach, Housing and Urbanization department of Iran, Architecture and Urban Design.2008.

[9] Azad Aramaleki, Taghi, Modernization Notion in Iran, Tehran University Publications, p. 15, 2001.

[10] Kalantari, Mohsen. Study of Crime Geography in Tehran Regions, PHD Thesis, Tehran University. 2002.

[11] Pilehvar. A.A. "Partnership, A New Approach for the Urban Management of Iran, Case Study- Management of Mashhad Religious Metropolis". International Journal of Sustainable Development and Planning, Vol 2, Number4. p.441, 2007.

[12] Hosseinzade Dalir, Karim., Effective Positions, Factors and Elements on Physical Development of Iran's Cities. Geography and Regional Development Magazine, Number 6, p 222, 2006.

[13] Habibi, Sayyed Mohsen., From Shar to city, Tehran University Publications, P. 159, 1996.

[14] Amirahmadi, Houshang, Urban Development Faced with Modernism and Planning Requirements, Translated by Sayyed Mahmood Nejati Hosseini, Urban Management Quarterly, Number 2, Summer, p. 80, 2001.

[15] Iran's Census Center, Public Counting of People and Housing, 1956-2006, entire Country. 2009.

[16] Pilehvar, Aliasghar and Ahmad, Pourahmad. Growth and Development Process of Iran's Metropolises. Geographical Research Quarterly, Number 48, summer. p.116, 2004.

[17] Mahdi zade, javad, et al., Strategic Urban Development Planning, Payame Sima Publcations, Tehran, p. 540, 2006. 